\title{
Potential role of hydrogen peroxide and melanin in the cold hardiness of Ostrinia nubilalis (Lepidoptera: Pyralidae)
}

\author{
DaniJela KOJIC ${ }^{1}$, Ivan SPASOJEVIC ${ }^{2}$, Miloš MOJOVIC ${ }^{3}$, DušKo BLAGOJEVIC 4 , M. Roger WORLAND 5 , \\ GordANA GRUBOR-LAJSIC ${ }^{1 *}$ and MiHAJlo B. SPASIC ${ }^{4}$
}

\author{
${ }^{1}$ Department of Biology and Ecology, Faculty of Sciences, University of Novi Sad, Trg Dositeja Obradovica 2, 21000 Novi Sad, \\ Serbia; e-mail: gordanagl@ib.ns.ac.yu \\ ${ }^{2}$ Center for Multidisciplinary Studies, University of Belgrade, Serbia \\ ${ }^{3}$ Faculty of Physical Chemistry, University of Belgrade, Serbia \\ ${ }^{4}$ Department of Physiology, Institute for Biological Research “Sinisa Stankovic”, Bulevar Despota Stefana 142, 11060 Belgrade, \\ Serbia \\ ${ }^{5}$ British Antarctic Survey, Natural Environment Research Council, High Cross, Madingley Road, Cambridge CB3 0ET, UK
}

Key words. Ostrinia nubilalis, antioxidant enzymes, melanin, hydrogen peroxide, cold-hardiness

\begin{abstract}
The aim of this study was to investigate the relationship between antioxidant enzymes and reactive oxygen species production in diapausing larvae of the European corn borer, Ostrinia nubilalis (Lepidoptera: Pyralidae) kept at $5^{\circ} \mathrm{C},-3^{\circ} \mathrm{C}$ and $-16^{\circ} \mathrm{C}$ for two weeks. The amount of hydrogen peroxide $\left(\mathrm{H}_{2} \mathrm{O}_{2}\right)$, activity of antioxidant enzymes, copper zinc superoxide dismutase (CuZnSOD), manganese superoxide dismutases (MnSOD) and catalase (CAT) in whole body homogenates, as well as the electron paramagnetic resonance (EPR) spectroscopy of this insect's whole body were analysed. A higher level of melanin radical and lower $\mathrm{CuZnSOD}$ and CAT activities were found in larvae kept at $-3^{\circ} \mathrm{C}$ than at $5^{\circ} \mathrm{C}$ and $-16^{\circ} \mathrm{C}$. At the same temperature $\left(-3^{\circ} \mathrm{C}\right)$ an elevated $\mathrm{H}_{2} \mathrm{O}_{2}$ concentration was recorded. A possible regulatory role of $\mathrm{H}_{2} \mathrm{O}_{2}$ at $-3^{\circ} \mathrm{C}$, which is the temperature that triggers freezing tolerance, is suggested.
\end{abstract}

\section{INTRODUCTION}

Studies on the mechanisms of cold-hardiness in insects include the regulation of physiological (Ramlov, 2000) and biochemical (Storey, 1997; Duman, 2001) processes that are involved in insect survival at subzero temperatures. A significant number of results indicate a relationship between the biochemical mechanisms of cold hardiness and processes regulated by free radicals and the antioxidant system (Rojas \& Leopold, 1996; Grubor-Lajsic et al., 1997; Joanisse \& Storey, 1998; Jovanovic-Galovic et al., 2004, 2007).

One of the most common responses of many species of insect when exposed to low environmental temperatures is the accumulation of low molecular weight organic solutes that act as cryoprotectants (Asahina, 1966; Lee et al., 1987; Storey \& Storey, 1988). Our previous studies (Stanic et al., 2004) show that the biosynthesis of glycerol as a cryoprotectant is closely associated with antioxidant enzymes in larvae of the European corn borer, Ostrinia nubilalis. The elevated activity of enzymes in the pentose phosphate pathway in Ostrinia larvae exposed to cold accord with data on the glycerol synthesis pathway (Nordin et al., 1984). Flux through the pentose phosphate pathway is critically important not only for polyol synthesis but also for generating the reducing equivalents (NADPH) needed for the antioxidant defense system (ADS). Investigations of the role of the ADS in the adaptation of insects to low temperatures (Blagojevic, 2007) show that ADS reduces the risk of oxidative damage and, also, optimizes concentration of reactive oxygen species (ROS). This is particularly important because ROS is involved in cellular signaling as part of the complex redox based physiological regulation (Schafer \& Buettner, 2001), including adaptation. At low/moderate concentrations hydrogen peroxide and other ROSs are involved in redox signalling and are key regulators of many intracellular pathways (Valko, 2007).

The aim of this work was to determine whether the response to cold is modulated by ROS and, also, whether the ROS homeostasis is adapted to the regulatory processes resulting in the cold resistance of larvae of Ostrinia nubilalis. We examined (1) the concentration of $\mathrm{H}_{2} \mathrm{O}_{2}$, and (2) the activities of some antioxidant enzymes (CuZnSOD, MnSOD and CAT), which may regulate the concentration of $\mathrm{H}_{2} \mathrm{O}_{2}$ in larvae of the European corn borer, Ostrinia nubilalis. In adittion, entire $O$. nubilalis larvae were analyzed by Electron Paramagnetic Resonance (EPR) spectroscopy.

\section{MATERIAL AND METHODS}

\section{Insects}

Diapausing fifth instars larvae of Ostrinia nubilalis were collected from maize plants growing in Vojvodina Province, Serbia. Insects were kept in a laboratory in humid conditions at $5^{\circ} \mathrm{C}$ for a week and then divided into the two groups, i.e. the first was kept at $5^{\circ} \mathrm{C}$ while the second was gradually exposed to $-3^{\circ} \mathrm{C}$ and $-16^{\circ} \mathrm{C}$ (temperature decreased over 8 days at $-3^{\circ} \mathrm{C}$ per day). They were kept at these temperatures for the next 2 weeks, when the samples were collected.

\section{Enzyme assays}

The enzyme activities were assayed in the supernatant of larval homogenates $(20 \% \mathrm{w} / \mathrm{v} 0.05 \mathrm{M}$ phosphate buffer, $\mathrm{pH} 7.0$, with $0.05 \%$ phenylthiourea). The total SOD activity was measured using the method described by McCord \& Fridovich (1968)

\footnotetext{
* Corrresponding author.
} 


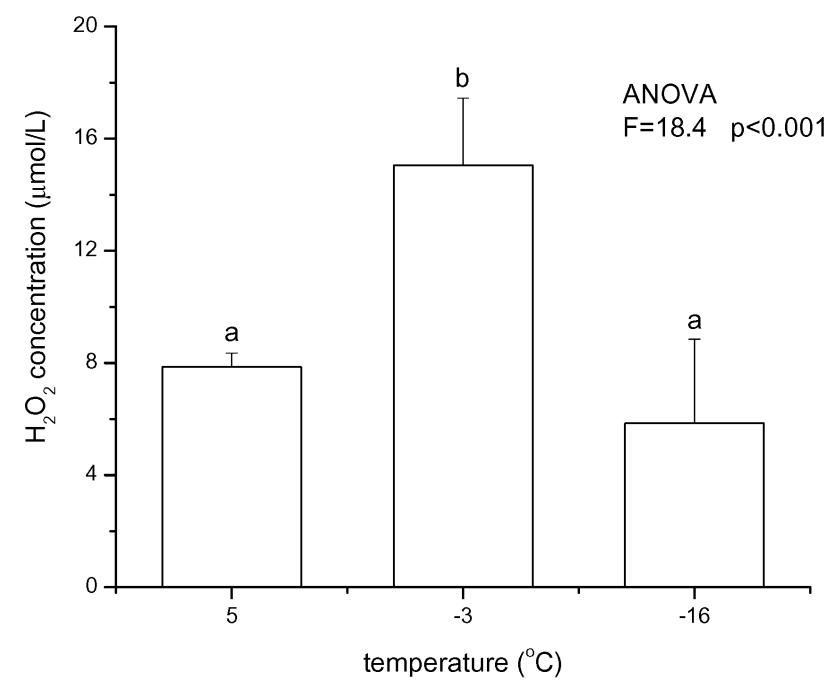

Fig. 1. Concentration of hydrogen peroxide in Ostrinia nubilalis larvae kept at $5,-3$ or $-16^{\circ} \mathrm{C}$. Results are presented as mean $\pm \mathrm{SD}(\mathrm{n}=3)$. Statistical significance of the differences was tested using one-way ANOVA and post hoc Tukey's HSD test. Different letters above bars indicate significant differences.

and the MnSOD activity by the same method after the sample was incubated with $2 \mathrm{mM} \mathrm{KCN}$ for $30 \mathrm{~min}$. The CuZnSOD activity was calculated as the total minus MnSOD activity. The activity of CAT was measured using the method of Aebi (1984). The protein content was determined using the method of Lowry (Lowry et al., 1951), with bovine serum albumin as the protein standard.

\section{$\mathrm{H}_{2} \mathrm{O}_{2}$ assay}

The $\mathrm{H}_{2} \mathrm{O}_{2}$ in body homogenates was detected using the Amplex Red reagent (Invitrogen, USA). Individual $100 \mu 1$ reactions included a $50 \mu \mathrm{l}$ sample of the homogenate $(5 \%$ whole body homogenate in $50 \mathrm{mM}$ sodium phosphate buffer, $\mathrm{pH}$ 7.4), $50 \mu \mathrm{M}$ Amplex Red reagent and $0.1 \mathrm{U} / \mathrm{ml}$ horseradish peroxidase (HRP). After incubation for $30 \mathrm{~min}$ at room temperature, fluorescence was measured using a fluorescence microplate reader with excitation at $544 \mathrm{~nm}$ and detection at $590 \mathrm{~nm}$.

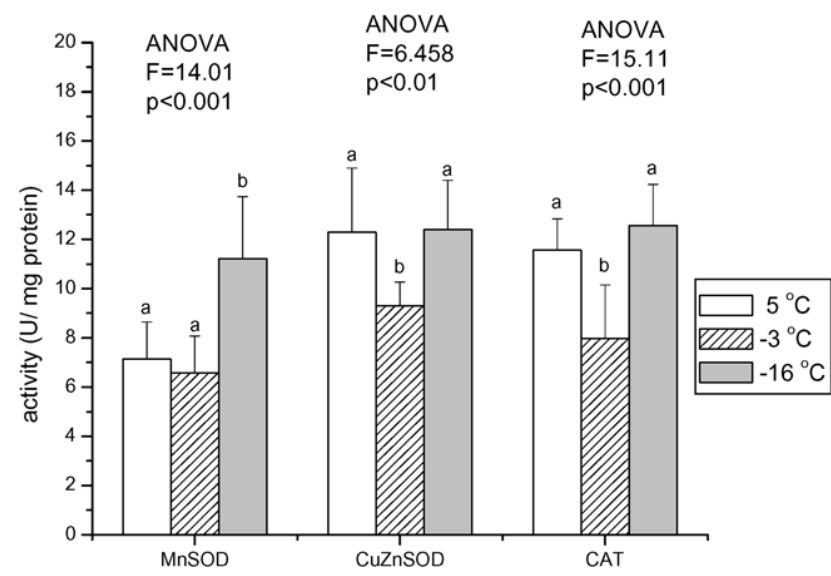

Fig. 2. Antioxidant enzymes in Ostrinia nubilalis larvae kept at $5,-3$ or $-16^{\circ} \mathrm{C}$. Results are presented as mean \pm SD $(n=8)$. Statistical significance of differences was tested using one-way ANOVA and post hoc Tukey's HSD test. Different letters above bars indicate significant differences.

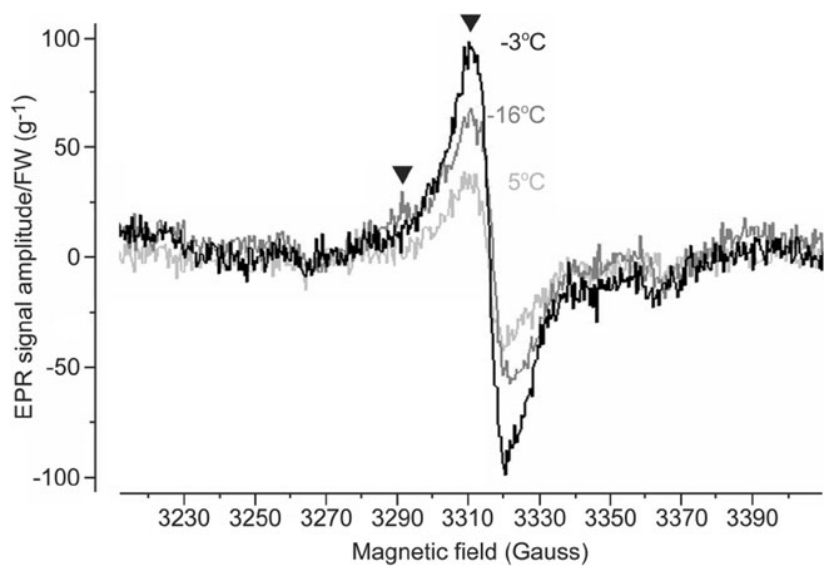

Fig. 3. EPR spectra of larvae kept at $-3^{\circ} \mathrm{C}$ (black trace), $-16^{\circ} \mathrm{C}$ (gray trace) or $5^{\circ} \mathrm{C}$ (light gray trace). Downward triangle (v) marks two characteristic melanin-related EPR peaks. Measurements were performed at $-150^{\circ} \mathrm{C}$. Measurements are for 8 larvae from each experimental group. Results are means \pm S.D. values of relative peak intensity/larval body mass.

\section{EPR spectroscopy}

The EPR spectra were recorded using a Varian E104-A EPR spectrometer operating at X-band $(9.51 \mathrm{GHz})$ and a temperature of $-150^{\circ} \mathrm{C}$. The following settings were used: $2 \mathrm{G}$ modulation amplitude, $100 \mathrm{kHz}$ modulation frequency, $10 \mathrm{~mW}$ microwave power, 200G field width and $3310 \mathrm{G}$ field centre. The spectra were recorded using EW software (Scientific Software Inc, Bloomington, IL, USA). Results are presented as mean \pm S.D. values of relative peak intensity / unit larval body mass.

\section{Data analysis}

All the values are expressed as mean $\pm \mathrm{SD}$. The data were analyzed using one-way analyses of variance (ANOVA) followed by Tukey's HSD test (Hinkle, 1994). The test criterion for statistical significance was $\mathrm{p}<0.01$.

\section{RESULTS}

The concentration of $\mathrm{H}_{2} \mathrm{O}_{2}$ was higher in larvae exposed to $-3^{\circ} \mathrm{C}$ than in those kept at $5^{\circ} \mathrm{C}$ and $-16^{\circ} \mathrm{C}$ (Fig. 1). Lower $\mathrm{CuZnSOD}$ and CAT activities were found at $-3^{\circ} \mathrm{C}$ than at the other two temperatures (Fig. 2). MnSOD activity was higher in larvae exposed to $-16^{\circ} \mathrm{C}$ than in those kept at $5^{\circ} \mathrm{C}$ and $-3^{\circ} \mathrm{C}$. (Fig. 2).

EPR spectra (Fig. 3) show the characteristic signal of melanin. Melanin-related peaks represent the stable semiquinone radicals from eumelanin (central peak) and pheomelanin (inflexion on the left side of the eumelanin signal), as reported earlier (Buszman et al., 2006; Meredith et al., 2006). Melaninrelated signals were obtained at both $-150^{\circ} \mathrm{C}$ (higher $\mathrm{S} / \mathrm{H}$ ratio) and at room temperature (data not shown). The eumelanin signal was significantly stronger in larvae exposed to $-3^{\circ} \mathrm{C}(198.1 \pm$ $\left.25.9 \mathrm{~g}^{-1}\right)$ than those kept at $-16^{\circ} \mathrm{C}\left(125.1 \pm 19.9 \mathrm{~g}^{-1}\right)$ or $5^{\circ} \mathrm{C}$ $\left(82.0 \pm 33.2 \mathrm{~g}^{-1}\right)$

\section{DISCUSSION}

In this study the concentration of $\mathrm{H}_{2} \mathrm{O}_{2}$ and the activities of SOD and CAT, which regulate the concentration of $\mathrm{H}_{2} \mathrm{O}_{2}$, and the presence of melanin (polymeric pigments capable of mediating oxydative stress) in the larvae of the European corn borer, Ostrinia nubilalis, reared at $5^{\circ} \mathrm{C}$ and subsequently exposed to $-3^{\circ} \mathrm{C}$ and $-16^{\circ} \mathrm{C}$, were determined. The higher level of $\mathrm{H}_{2} \mathrm{O}_{2}$ at $-3^{\circ} \mathrm{C}$ than at either $5^{\circ} \mathrm{C}$ or $-16^{\circ} \mathrm{C}$ (Fig. 1) indicate that this reac- 
tive molecule may be involved in the metabolic adjustments characteristic of cold-hardy insects. It is known that $\mathrm{H}_{2} \mathrm{O}_{2}$ induces the intracellular accumulation of trehalose (Benaroudj et al., 2001), which is an important anhydroprotectant found in many freeze tolerant organisms.

The increased level of $\mathrm{H}_{2} \mathrm{O}_{2}$ could be a consequence of reduced CAT activity, which is in agreement with the significant decrease in CAT activity in larvae exposed to $-3^{\circ} \mathrm{C}$ (compared to those exposed to $5^{\circ} \mathrm{C}$ or $-16^{\circ} \mathrm{C}$ ) (Fig. 2). Moreover, the increased level of $\mathrm{H}_{2} \mathrm{O}_{2}$ at $-3^{\circ} \mathrm{C}$ correlates with the decrease in CuZnSOD activity, possibly because $\mathrm{H}_{2} \mathrm{O}_{2}$ provokes a slow, irreversible inactivation of CuZnSOD (Bray, 1974; Salo et al., 1990) without inactivating MnSOD (Asada et al., 1975; Fridovich, 1986). This could explain why the larvae exposed to $-16^{\circ} \mathrm{C}$ exhibited higher levels of MnSOD activity than those exposed to either $5^{\circ} \mathrm{C}$ or $-3^{\circ} \mathrm{C}$ (Fig. 2). The biological significance of MnSOD as a mitochondrial antioxidant enzyme and its contribution to cell signalling is under intensive investigation (Murphy, 2009).

In addition to dismutation of superoxide radicals, $\mathrm{H}_{2} \mathrm{O}_{2}$ can be generated in cells via polymerization reactions of quinonic melanogenic intermediates during melanin synthesis (JimenezCervantes et al., 2001). This may explain the increased levels of two characteristic melanin-related EPR signals (eumelanin and pheomelanin) coincident with the elevated $\mathrm{H}_{2} \mathrm{O}_{2}$ concentration $\left(-3^{\circ} \mathrm{C}\right)$ we recorded (Fig. 3). Moreover, as these two semiquinone radicals result from the reaction of melanin with free radicals (Meredith et al., 2006), the observed increase in the eumelanin signal could indicate the scavenging of radicals generated in response to exposure to cold stress.

On the basis of our results it may be concluded that the $\mathrm{H}_{2} \mathrm{O}_{2}$ level, tuned via antioxidant enzymes optimizing the concentration of ROS and radical properties of melanin, could be a part of the alterations in redox involved in processes that account for the cold-hardiness of Ostrinia nubilalis.

ACKNOWLEDGEMENTS. This research was funded by the Ministry for Science and Environment Protection of the Republic of Serbia, Grant No. 143034B "The role of redoxactive substances in the maintenance of homeostasis". We also wish to thank M.S. Clark and BAS (Cambridge, UK) for financially supporting this investigation as the part of EU Sleeping Beauty Project. Our thanks also go to W. Block for critical reading of the manuscript.

\section{REFERENCES}

Aebi H. 1984: Catalase in vitro. Methods Enzymol. 105: 121-126.

Asada K., Yoshikawa K., Takahashi M.A., Maeda Y. \& ENMANJI K. 1975: Superoxide dismutases from blue-green alga, Plectonema boryanum. J. Biol. Chem. 250: 2801-2807.

Asahina E. 1966: Freezing and frost resistance in insects. In Meryman H.T. (ed.): Cryobiology. Academic Press, New York, pp. 451-486.

Benaroudj N., Lee D.H. \& Goldber A.L. 2001: Trehalose accumulation during cellular stress protects cells and cellular proteins from damage by oxygen radicals. J. Biol. Chem. 276: 24261-24267.

Blagojević D. 2007: Free radical-mediated stress and antioxidant defence in organisms subjected to low temperatures. CryoLetters 28: 137-150.

Bray R.C., Cockle S.A., Fielden E.M., Roberts P.B., Rotilio G. \& CAlABRese L. 1974: Reduction and inactivation of superoxide dismutase by hydrogen peroxide. Biochem. J. 139: $43-48$.
Buszman E., Pilawa B., Zdybel M., Wilczynski S., Gondzik A., WitosZYNSKA T. \& WiLCZOK T. 2006: EPR examination of $\mathrm{Zn}^{2+}$ and $\mathrm{Cu}^{2+}$ binding by pigmented soil fungi Cladosporium cladosporioides. Sci. Total Envir. 363: 195-205.

Duman J.G. 2001: Antifreeze and ice nucleator proteins in terrestrial arthropods. Annu. Rev. Physiol. 63: 327-357.

Fridovich I. 1986: Superoxide dismutases. Adv. Enzymol. Relat. Areas Mol. Biol. 56: 61-97.

Grubor-Lajsic G., Block W., Telesmanic M., Jovanovic A., Stevanovic D. \& Baca F. 1997. Effect of cold acclimation on the antioxidant defense system of two larval Lepidoptera (Noctuidae). Arch. Insect Biochem. Physiol. 36: 1-10.

Hinkle E.D., Wiersma W. \& Jurs G.S. 1994: Applied Statistics for Behavioral Sciences. 3rd ed. Houghton Mifflin, Boston, $706 \mathrm{pp}$.

Jiménez-Cervantes M., Pérez C., Daum N., Solano F. \& García-Borrón J.C. 2001: Inhibition of melanogenesis in response to oxidative stress: transient downregulation of melanocyte differentiation markers and possible involvement of microphthalmia transcription factor. J. Cell Sci. 114: 2335-2344.

JoANISSE D.R. \& StoRey K.B. 1998: Oxidative stress and antioxidants in stress and recovery of cold-hardy insects. Insect Biochem. Mol. Biol. 28: 23-30.

Jovanovic-Galovic A., Blagojevic D., Grubor-Lajsic G., WorLAND R. \& SPASIC M.B. 2004: Role of antioxidant defense during different stages of preadult life cycle in European corn borer (Ostrinia nubilalis, Hübn.): diapause and metamorphosis. Arch. Insect Biochem. Physiol. 55: 79-89.

Jovanovic-Galovic A., Blagojevic D.P., Grubor-Lajsic G., Worland M.R. \& Spasic M.B. 2007: Antioxidant defense in mitochondria during diapause and postdiapause development of European corn borer (Ostrinia nubilalis Hübn.) Arch. Insect Biochem. Physiol. 64: 111-119.

Lee R.E. JR., Chen C.P., Meacham M.H. \& Denlinger D.L. 1987: Ontogenetic patterns of cold-hardiness and glycerol production in Sarcophaga crassipalpis. J. Insect Physiol. 33: 567-592.

Lowry O.H., Rosenbrough N.J., Farr A.L. \& Randal R.J. 1951: Protein measurement with the Folin phenol reagent. $J$. Biol. Chem. 193: 265-275.

McCord J.M. \& Fridovich I. 1968: The reduction of cytochrome c by milk xanthine oxidase. J. Biol. Chem. 243: 5753-5760.

Meredith P., Powell B.J., Riesz J., Nighswander-Rempel S.P., Pederson M.R. \& Moore E.G. 2006: Towards structureproperty-function relationships for eumelanin. Soft Matter 2: $37-44$.

Murphy M.P. 2009: How mitochondria produce reactive oxygen species. Biochem. J. 417: 1-13.

Nordin H.J., Cui Z. \& Yin C.-M. 1984: Cold-induced glycerol accumulation by Ostrinia nubilalis larvae is developmentally regulated. J. Insect Physiol. 30: 563-566.

RAMLOV H. 2000: Aspects of natural cold tolerance in ectothermic animals. Hum. Reprod. 15: 25-46.

RoJAs R.R. \& LEOPOLD R.A. 1996: Chilling injury in the housefly: Evidence for the role of oxidative stress between pupariation and emergence. Cryobiology 33: 447-458.

Salo D.C., Pacifici R.E., Lin S.W., Giulivi C. \& Davies K.J.A. 1990: Superoxide dismutase undergoes proteolysis and fragmentation following oxidative modification and inactivation. J. Biol. Chem. 265: 11919-11927.

Schafer F.Q. \& Buettner G.R. 2001: Redox environment of the cell as viewed through the redox state of the glutathione 
disulfide/glutathione couple. Free Rad. Biol. Med. 30: $1191-1212$.

Stanic B., Jovanovic-Galovic A., Blagojevic D., GruborLajsic G., Worland R. \& Spasic M.B. 2004: Cold hardiness in Ostrinia nubilalis (Lepidoptera: Pyralidae): Glycerol content, hexose monophosphate shunt activity and antioxidative defense system. Eur. J. Entomol. 101: 459-466.

Storey K.B. 1997: Organic solutes in freezing tolerance. Comp. Biochem. Physiol. (A) 117: 319-326.
Storey K.B. \& Storey J.M. 1988: Freeze tolerance in animals. Physiol. Rev. 68: 27-84.

Valko M., Leibfritz D., Moncol J., Cronin M.T.D., Mazur M. \& TELSER J. 2007: Free radicals and antioxidants in normal physiological functions and human disease. Int. J. Biochem. Cell Biol. 39: 44-84.

Received February 5, 2009; revised and accepted April 14, 2009 